\title{
Microbial fossil record of rocks from the Ross Desert, Antarctica: implications in the search for past life on Mars
}

\author{
Jacek Wierzchos' and Carmen Ascaso ${ }^{2}$ \\ ${ }^{1}$ Servei de Microscopia Electronica, Universitat de Lleida, c/Rovira Roure, 44, 25198 Lleida, Spain \\ ${ }^{2}$ Centro de Ciencias Medioambientales, CSIC, c/Serrano, 115 bis, 28006 Madrid, Spain \\ e-mail:jacekw@suic-me.udl.es
}

\begin{abstract}
Cryptoendolithic microbial communities living within Antarctic rocks are an example of survival in an extremely cold and dry environment. The extinction of these micro-organisms formerly colonizing sandstone in the Mount Fleming area (Ross Desert), was probably provoked by the hostile environment. This is considered to be a good terrestrial analogue of the first stage of the disappearance of possible life on early Mars. To date, only macroscopically observed indirect biomarkers of the past activity of cryptoendoliths in Antarctic rocks have been described. The present paper confirms, for the first time, the existence of cryptoendolith microbial fossils within these sandstone rocks. The novel in situ application of scanning electron microscopy with backscattered electron imaging and simultaneous use of X-ray energy dispersive spectroscopy allowed the clear detection of microfossils left behind by Antarctic endoliths. Careful interpretation of the morphological features of cells, such as preserved cell walls in algae, fungi and bacteria, cytoplasm elements such as chloroplast membranes in algae and organic matter traces, mineral associations, and the spatial context of these structures all point to their identification as cryptoendolith microfossils. This type of investigation will prompt the development of research strategies aimed at locating and identifying the signs that Martian microbiota, probably only bacteria if they existed, may have been left for us to see.
\end{abstract}

Received 25 September 2001

Key words: Antarctica, backscattered electrons, cryptoendoliths, microbial fossils and Ross Desert.

\section{Introduction}

The search for the oldest traces of life on Earth (e.g. Schopf \& Walter 1983; Awramik et al. 1983; Hofman \& Schopf 1983) has revealed that life was present at an early stage in the history of our planet $(3.5 \mathrm{Gya})$ and must therefore have originated relatively rapidly (Wilde et al. 2001). The hypothesis that there may have been life on Mars (Davis \& McKay 1996) was based on the presence of liquid water and on the similarity between the environmental conditions of early Mars and early Earth.

Since liquid water is essential for life, it was suggested that possible life on Mars would have gradually disappeared when this planet became colder and drier (Friedmann \& Koriem 1989). Now, Mars is a cold desert, much more extreme than any cold, dry environment found on Earth. Nevertheless, Antarctica and, in particular, the cold, dry and icy extensive Ross Desert zone $\left(76.5^{\circ}-78.5^{\circ} \mathrm{S}, 160^{\circ}-164^{\circ} \mathrm{E}\right)$ provides the best terrestrial analogue for Martian conditions, when putative Martian life became extinct from the regolith surface. Antarctic microbial ecosystems thus provide an excellent testing ground for theories of astrobiology and for the question of life and its extinction on Mars (McKay et al. 1992; McKay 1993).

Several studies have shown that sandstone rocks from the
Ross Desert are colonized by endolithic micro-organisms (Friedmann \& Ocampo 1976; Friedmann 1980, 1982; Friedmann et al. 1981, 1988; Friedmann \& Koriem 1989; Kappen 1993; Wierzchos \& Ascaso 2001). The principal habitat for microbial life in this dry, cold desert is a narrow zone under the sandstone rock surface (Friedmann 1982). The narrow fissures, cracks and pores between mineral grains provide a comparatively milder microenvironment for the survival of cryptoendolithic and/or chasmoendolithic (Golubic et al. 1981) cyanobacteria and lichens than the rock surface.

Friedmann et al. (1994) hypothesized that a quantifiable gradient from relatively 'mild' (favourable to life) to 'hostile' (adverse to life) environments exist in the Antarctic desert. The principal environmental factor, which determines the limit of life, was defined in terms of temperature (Friedmann et al. 1994). According to these authors, the 'limit of life' that separates the hostile and milder environments runs through the Mount Fleming area. It was suggested that indeed in this area of the Ross Desert, inhabiting organisms reached the extreme limits of their physiological tolerance, which led to the extinction of microbial life (Friedmann \& Koriem 1989; Friedmann et al. 1994).

The challenging question is: can we find the remains of 
these decayed micro-organisms in the form of fossils within these Antarctic rocks?

To date only two types of microbial indirect trace-fossil formations associated with the past biological activity of cryptoendolithic micro-organisms in Antarctic rocks have been described after macroscopic observation. The first was the formation of an iron leaching layer due to the mobilization of iron hydroxides, attributed to the activity of cryptoendolithic lichens (Friedmann \& Weed 1987). The second corresponds to geophysical bioweathering resulting from the diminished cohesion of sandstone grains, which leads to the formation of exfoliation mosaic patterns (Friedmann \& Weed 1987; Kappen 1993; Sun \& Friedmann 1999). Detecting traces of past life in these rocks requires much further work, but on a microscopic scale of observation using microscopy and microanalytical techniques.

The most commonly used technique in the study of microorganism fossils is light microscopy. Nevertheless, its relatively low resolution and lack of microanalytical applications is an important limitation for the irrefutable identification of microstructures morphologically reminiscent of lifeforms, considered as microfossils (Barker et al. 1997). Another viable method is transmission electron microscopy (Westall 1994, 1999; Westall et al. 1995; Liebig et al. 1996), which has the drawback that it may not be applied to all kinds of hard petrologic material. Scanning electron microscopy (SEM) used in the conventional secondary electron (SE) detection mode yields topographical images of the rock surface. However, this technique only provides an external morphological description of putative fossilized cells and is incapable of distinguishing between abiotic fossils of similar morphologies. Several researchers have even suggested microfossil-like structures observed by SEM to be abiotic biomorphs, with shapes that resemble living organisms (e.g. Steele et al. 1998; Garcia-Ruiz 1999).

As reported here, SEM with backscattered electron detection (SEM-BSE) plus an auxiliary X-ray energy dispersive spectroscopy (EDS) microanalytical system, seems to be the ideal tool for the in situ visualization and microanalysis of individual microscopic fossils.

The aim of the present investigation was to demonstrate the presence of micro-organism fossils within Antarctic sandstone rocks. In particular, results obtained in this initial study demonstrate the applicability and novel possibilities of the SEM-BSE and EDS investigation strategy for the in situ analysis of micrometre fossils and provides images of mineralized elements that are true to the shapes of the ultrastructural components of cells. This search for new methods of detecting traces of life within Antarctic rocks may have important implications in the field of astrobiology.

\section{Materials}

Pieces of sandstone rock were collected by E.I. Friedmann from two zones of the Ross Desert (McMurdo Dry Valleys). Specimens A834/577 from the harsh Mount Fleming region $\left(77^{\circ} 33^{\prime} \mathrm{S}, 160^{\circ} 06^{\prime} \mathrm{E}, 2200 \mathrm{~m}\right.$ altitude) were collected over the year 1983-84. Mean annual air and rock temperature in 1993 was reported as: -24.9 and $-24.2{ }^{\circ} \mathrm{C}$, respectively, for this area (Friedmann et al. 1994). The rocks were air-dried, and stored in an air-conditioned room (at $20{ }^{\circ} \mathrm{C}$ ) until use. Specimens A945/6, from the milder zone of the Tyrol Valley $\left(77^{\circ} 58^{\prime} \mathrm{S}, 160^{\circ} 63^{\prime} \mathrm{E}\right)$ and colonized by cryptoendolithic lichens were collected during 1994-95. This sample was shipped frozen and stored at $-23{ }^{\circ} \mathrm{C}$ at the Antarctic Research Facility, Florida State University until use. Mineralogical characterization of the $5 \mathrm{~mm}$ surface layer of A834/577 was performed by X-ray powder diffraction using a BraggBrentano theta/2theta Siemens D-500 diffractometer $(\mathrm{CuK} \alpha$ radiation) equipped with a secondary graphite monochromator.

\section{Methods}

The rock samples from the Tyrol Valley (A945/6), which contained live cryptoendolithic lichens, were processed for SEM-BSE and/or EDS analysis according to a method developed by Wierzchos \& Ascaso (1994). Since the intensity of the BSE signal depends on the mean atomic number of the sample, the SEM-BSE technique not only permits the discrimination of inorganic features (important in microfossil identification procedures), but also it is possible to identify heavy metal-stained ultrastructural elements of live material. In brief, the stone fragments, once fixed $(3.25 \%$ glutaraldehyde followed by $1 \% \mathrm{OsO}_{4}$ ) and dehydrated in an ethanol series, were embedded in LR White resin. Uranyl acetate saturated with $70 \%$ ethanol was added during the dehydration process. After polymerization, the blocks were cut, finely polished at the ends with diamond powder $(0.1 \mu \mathrm{m})$ and coated with $10 \mathrm{~nm}$ of carbon. Transverse sections of the polished surfaces of the rocks were examined using a DSM 940 A Zeiss SEM instrument equipped with a four-diode, semiconductor BSE detector and a Link ISIS microanalytical EDS system. SEM-BSE and EDS examination of the samples were performed simultaneously. Microscopy and/or microanalytical operating conditions were as follows : $0^{\circ}$ tilt angle, $35^{\circ}$ take-off angle, $15 \mathrm{kV}$ acceleration potential, 6 or $25 \mathrm{~mm}$ working distance and $15 \mathrm{nA}$ specimen current. The EDS method involved qualitative and quantitative microanalysis, including the spatial distribution of elements and microprobe profiles.

To avoid any possible contaminants, the sample from the hostile Mount Fleming environment (A834/577) harbouring putative microfossils was not subjected to any type of chemical treatment prior to inclusion in LR White resin. After embedding and polymerization, specimens were processed and subjected to SEM-BSE and EDS analysis in the same way as the A945/6 samples.

\section{Results and discussion}

\section{Live Antarctic cryptoendoliths}

The application of the SEM-BSE technique to the in situ study of lithobiontic micro-organisms has been reported extensively 


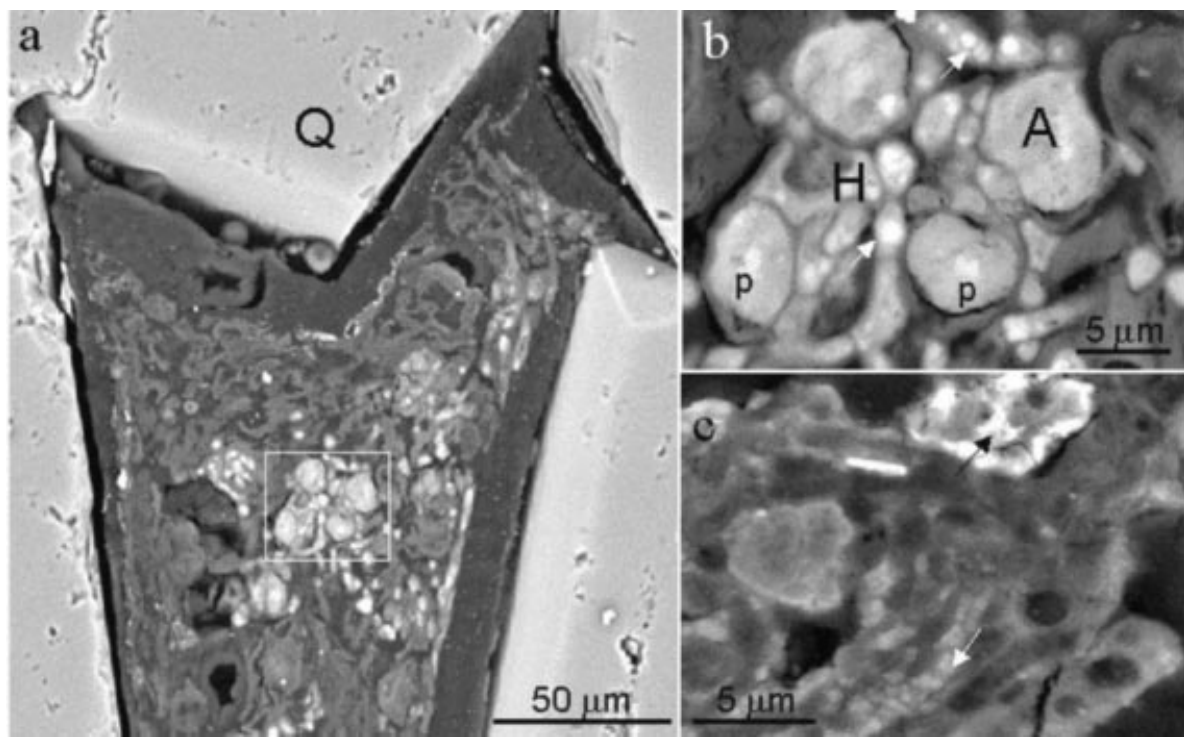

Fig. 1. SEM-BSE images of cryptoendolithic communities within Antarctic sandstone from the Tyrol Valley. (a) Cryptoendolithic lichen occupying a pore space between quartz (Q) grains in the sandstone. (b) Detailed view of the area outlined in (a) showing photobiont (A) and mycobiont $(\mathrm{H})$ cells forming the cryptoendolithic lichen; $\mathrm{p}$, pyrenoid in a trebouxoid-type alga; white arrow, lipid bodies in a hyphal cell. (c) Remnants of dead cryptoendolithic micro-organisms within the same rock; black arrow: FeO-rich mineral; white arrow: small grains of a SiAl-K-Fe-O-rich mineral.

by Wierzchos \& Ascaso (1994), Ascaso \& Wierzchos (1994), Ascaso et al. (1995) and Ascaso et al. (1998). An update on the visualization of cryptoendolithic Antarctic communities using this method is provided in Wierzchos \& Ascaso (2001) and Wierzchos et al. (2002). To demonstrate the potential use of these techniques on live endoliths, Fig. 1 shows SEM-BSE images of cryptoendolithic lichen cells (algae and fungi) colonizing the Tyrol Valley sandstone rock. Fig. 1(a) shows micro-organism cells occupying a pore space between quartz grains. Note, that parts of the algal and hyphal cells appear to be alive as they are capable of absorbing heavy metal staining compounds (brighter BSE signal). Details of these biologically active cells are shown in Fig. 1(b), where the ultrastructural elements of the photobiont and mycobiont cells may be observed. In these algal cells (Fig. 1b), pyrenoids (p) may be seen in the central zone. This indicates that these algae are of the trebouxoid type. In live hyphal cells, lipid globules (white arrows in Fig. 1b) are clearly distinguished. Despite the Tyrol Valley zone being considered by Friedmann et al. (1994) to have a milder climate than the Ross Desert area, most of the pores of this rock are filled with dead cells. Using TEM, Friedmann \& Koriem (1989) described the damage incurred by endolithic cells from the Ross Desert leading to their death. The SEM-BSE image in Fig. 1(c) shows the remnants of dead micro-organisms colonizing Tyrol Valley sandstone. The fixing and staining compounds are not well absorbed, indicating only mummified remains of micro-organisms. The bright deposits, which surround cell debris, are high in iron oxide (black arrow in Fig. 1c) and the grey-coloured inorganic deposits (white arrow in Fig. 1c) are rich in $\mathrm{O}, \mathrm{Fe}, \mathrm{Si}, \mathrm{Al}$ and $\mathrm{K}$, confirmed by EDS microanalysis. This biomobilized precipitation of inorganic compounds may be interpreted as a biomarker of microbial activity (Wierzchos et al. 2002). The precipitation of minerals inside, outside or even some distance away from living or dead microbial cells has been reported by Ferris et al. (1988) and Fortin et al. (1997). Indeed, the mummified cells with their corresponding diagenetic inorganic deposits may be the result of the first stage of a peculiar biogenic process, which eventually leads to the fossilization of cryptoendolithic cells. This would presumably occur, when climatic conditions became too severe for the survival of cryptoendoliths.

\section{Fossils of Antarctic cryptoendoliths}

If extensive biomobilization of elements occurs when microorganisms are biologically active and/or after their decay, the possibility of micro-organism fossil formation elsewhere may not be excluded. Indeed, this was shown by sandstone rocks from the harsh climatic conditions of the Mt Fleming zone. Figs 2 and 3 show what we consider to be fossilized cells of a micro-organism visualized by SEM-BSE (EDS) found within these rocks. This application of the SEM-BSE technique for the study of micro-organism fossils and/or biomarkers has been reported recently (Ascaso 2000; Konhauser et al. 2000; McKinley et al. 2000; Friedmann et al. 2001; Wierzchos \& Ascaso 2001; Wierzchos et al. 2002). We consider this technique to be an ideal tool for the detection, description and characterization of microbial fossils. The BSE signal is strongly dependent on the mean atomic number $(Z)$ of the target (Joy 1991), thus nanometric structures with differences in $Z$ greater than 0.1 may be resolved. Moreover, using this technique it is possible to scan finely polished samples from low to very high magnification (up to $50000 \times$ ) thus permitting continuous visualization of all levels of information. 

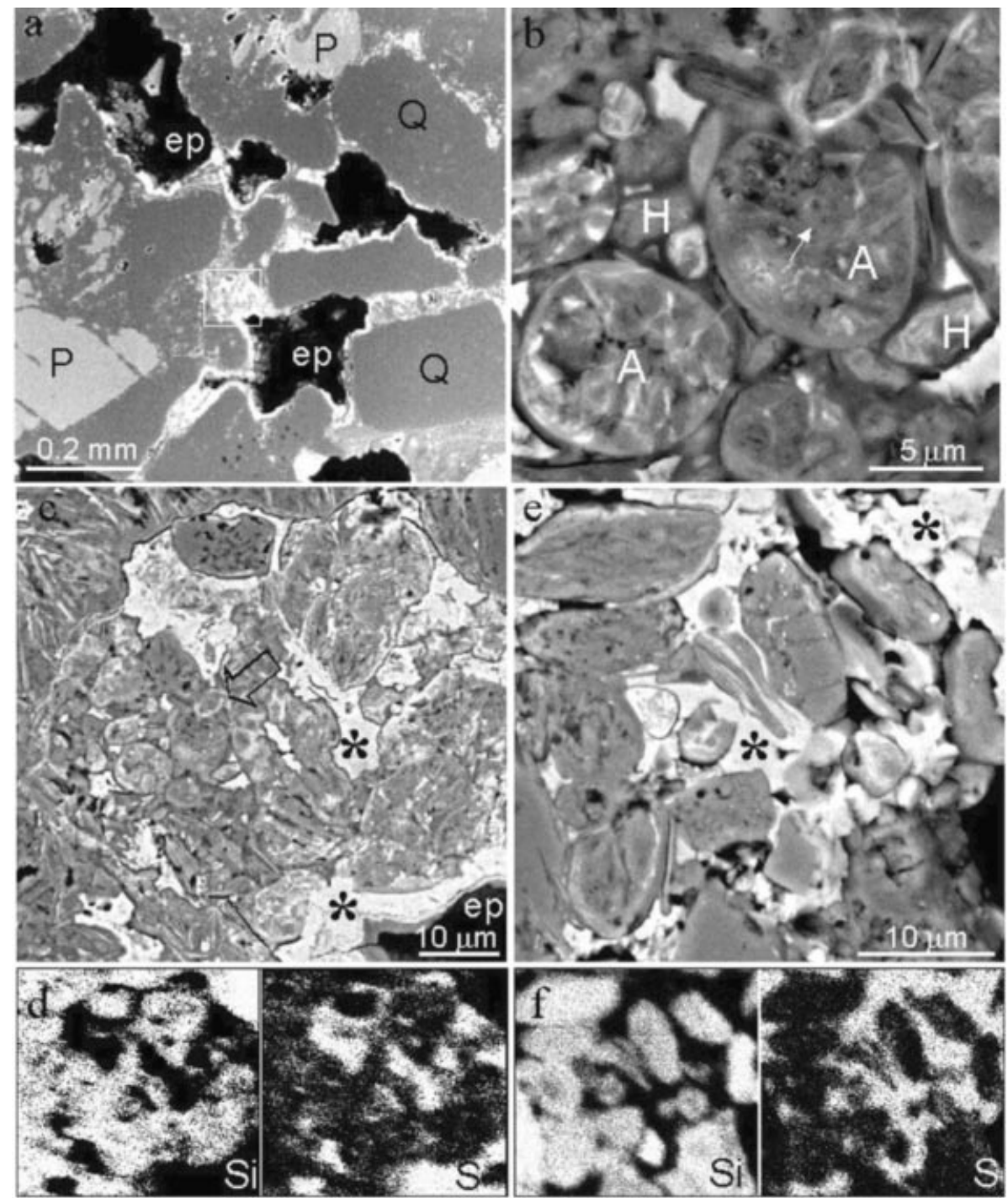

Fig. 2. SEM-BSE images and EDS elemental distribution maps of fossilized cryptoendolithic micro-organisms within Antarctic sandstone rock from Mt Fleming. (a) General SEM-BSE view of a pore system, about $2 \mathrm{~mm}$ below the sandstone rock surface; Q, quartz grains; P, plagioclase grains; ep, empty pores; the marked area is enlarged in (b) and (c). (b) Detailed SEM-BSE view of the zone marked by an arrow in (c) showing fossilized cryptoendolithic lichen algal (A) and hyphal $(\mathrm{H})$ cells; arrow, pyrenoid structure within the fossilized alga. (c) SEMBSE image showing fossilized cells of a cryptoendolithic lichen. The bright areas (asterisks) are jarosite (K-Fe-S-O determined by EDS microanalysis and confirmed by XRD) infillings that penetrated between fossilized cells and covered the pore walls (also see (a)); ep, empty pore; arrow indicates the area enlarged in (b). (d) EDS spatial distribution maps of $\mathrm{Si}$, corresponding to fossilized cell structures (left), and of S corresponding to the jarosite phase (right) shown in (c). (e) SEM-BSE image of fossilized cells embedded in jarosite (asterisks). (f) As in (d) but for the SEM-BSE image shown in (e).

The images in Fig. 2 show fossilized microbial cells found within the Mt Fleming sandstone. The SEM-BSE image in Fig. 2(a) provides a low-magnification view of the pore system within this rock. Quartz grains and plagioclase crystals were observed using SEM-BSE and determined by EDS microanalysis. XRD analysis confirmed the presence of quartz as an essential mineral, and plagioclase and orthoclase as accessory minerals, and served to determine the presence of trace minerals such as jarosite $\left[\mathrm{KFe}_{3}\left(\mathrm{SO}_{4}\right) 2(\mathrm{OH})_{6}\right.$, geothite, gypsum and calcite. It may be observed that the walls of larger pores and narrow fissures are covered and filled with bright (BSE signal) material. A more detailed view (Fig. 2c) of a pore area (marked by an asterisk in Fig. 2a) $2 \mathrm{~mm}$ below the rock surface, shows many infillings that resemble fossilized microbial cells in shape and size. The closer SEM-BSE view (Fig. $2 \mathrm{~b}$ ), shows fossilized algal and hyphal cells. Surprisingly, even the relics of ultrastructural elements of the chloroplast within the fossilized algae could be resolved, such as the pyrenoid zone (white arrow in Fig. 2b) in the central algal fossil cell. The walls of totally mineralized cells may be clearly distinguished. The dark contrast of the fossilized cell walls suggests that a light element (low atomic number), perhaps carbon, is still present. The appearance of carbon traces in fossilized plant cell walls was reported by Boyce et al. (2001) and in cyanobacteria microfossils by House et al. (2000). Minute black dots were frequently observed in the SEM-BSE images within the 
algal fossilized cells (Fig. 2b), indicating the presence of remnants of organic matter. It was not possible to perform EDS microanalysis on these dots because of the extremely small size of the structures and background overprinting of minerals. The SEM-SE image (topographical view) of the same area, shows no micropores where the black dots were observed in the SEM-BSE images. We interpret these black dots as being the degradation products of algal cells composed of organic matter, probably of a kerogen nature. These might be determined by laser Raman micro-spectroscopy (Russell et al. 1998). Kerogen inclusions associated with fossilized bacteria were reported by McKinley et al. (2000). The close presence of smaller $(\sim 2 \mu \mathrm{m}$ in diameter $)$ fossilized cells (hyphal) and larger ( $\sim 8 \mu \mathrm{m}$ in diameter) fossilized cells (algal) (Fig. 2b) leads us to conclude that in this pore space we have an excellent example of a fossilized cryptoendolithic lichen. These fossilized features and their morphologies may be compared with the organization of live cryptoendolithic lichens shown in Figs 1(a) and (b). These lichens show a different organization from the 'typical' lichen thallus. In some Antarctic cryptoendolithic lichens, the masses of fungal hyphae do not form an upper cortex and medulla, and the mycobiont forms characteristic structures in the algal zones by enclosing groups of algal cells (phycobiont).

The association between fossilized hyphae and algal cells could not always be clearly observed in further fragments of the A834/577 sample. The SEM-BSE image in Fig. 2(e) shows the fossilized cells of endolithic micro-organisms. Some are probably algal cells, deformed perhaps due to the fossilization process or even post mortem. Most of these cells have easily distinguished cell walls and less well-defined interior structures. In Figs 2(b)-(e), all of these fossilized cells show a similar chemical composition on EDS microanalysis. Most are mainly composed of $\mathrm{Si}$ and $\mathrm{O}$, indicating that silica was a principal agent responsible for the permineralization of live and/or mummified cryptoendolithic cells. The Si distribution maps corresponding to the areas in Fig. 2(c) and (e) are provided in Fig. 2(d) and (f), respectively. Note that the distribution of $\mathrm{Si}$ in these maps coincides with that of the fossilized cell structures.

The natural and experimental permineralization of live and/or dead micro-organisms by means of silicification has been extensively reported (e.g. Westall 1999; Boyce et al. 2001). It was stated that silica in solution (as silicic acid) nucleates into certain active groups, such as $\mathrm{CO}, \mathrm{OH}$ or $\mathrm{PO}_{3}$, in the organic template. The silica gradually hydrolyses, followed by polymerization and the subsequent preservation of the organic structure (Leo \& Barghoorn 1976). The absence of organic material in many permineralizations is thought to indicate secondary mineralization following the eventual oxidation of templating organic materials (Schopf 1975). Nevertheless, the degradation of cellular structures produced by the experimental silicification process leading to morphological changes in the micro-organisms was reported by Francis et al. (1978).

In the case of Antarctic cryptoendolithic microbial fossils, the question that arises is : how did they become permineralized by silica in solution, in the limited presence of water and at such low temperatures? Any hypothesis proposed needs to take into account the geological time-scale and the extensive time periods that Antarctic endoliths are able to survive in this extreme environment. It has been observed that the cryptoendolithic community is metabolically active for only several hundred hours per year (Friedmann et al. 1987) and has an extraordinarily slow growth and decay rate. Indeed, these communities possibly represent the slowest-growing organisms on Earth (Sun \& Friedmann 1999). On the other hand, the approximate age of trace fossils, which take the form of biogenous weathering (exfoliation) patterns, has been reported to be of the order of 10000 years (Sun \& Friedmann 1999). Accordingly, based on the date reported by Friedmann $\&$ Weed (1987) and estimates related to quartz-rind thickness calibration, it is proposed that the endolithic communities have inhabited the Ross Desert for the last few million years. It is clear that many geophysical and geochemical events have occurred during this large time period.

An example of the 'last' geological process that took place in the Mt Fleming region is the infiltration of jarosite in the rock pore system. As a result of this, the pore walls and narrow fissures were covered with this mineral (Fig. 2a). In Fig. 2(c) and (e), we can observe that microbial fossils are surrounded by a bright (BSE signal) matrix. According to the EDS microprobe, this inorganic phase is potassium jarosite and its presence was confirmed by XRD analysis. The presence of nanoscopic spots of this mineral rich in $\mathrm{K}, \mathrm{Fe}, \mathrm{S}$ and $\mathrm{O}$ (EDS) was even observed within the fossilized cells (e.g. bright spots in the microfossils in Fig. 2b,e). Jarosite surrounding the fossil cells is shown by the $\mathrm{S}$ distribution EDS maps in Fig. 2(d) and (f) corresponding to the SEM-BSE images in Fig. 2(c) and (e), respectively. The origin of jarosite in this rock is unknown and we can only hypothesize that the source of this mineral could be attributed to pyrite weathering in this sedimented sandstone rock (e.g. Nordstrom 1982).

Taking into account the extraordinarily slow growth rate of the Antarctic cryptoendoliths and the long time periods, one might expect different patterns of permineralization and/or mineral substitution leading to microfossil formation. Indeed, Fig. 3(a)-(c) illustrate processes other than the 'simple' silicification process of cryptoendolithic fossils preservation. The SEM-BSE image in Fig. 3(a) shows the fossilized cells of algae and fungi. Note that cell walls and cytoplasm structures, such as chloroplast envelopes, thylakoids (white arrows and inset in Fig. 3a) and pyrenoids (black arrow in Fig. 3a) can be discerned in the fossilized algal cells. A high degree of heterogeneity in the chemical composition of these fossilized cells and extracellular infiltrated spaces was shown by EDS analysis. The presence of Si-Al-Na-K-Fe-S-Ti-O within the microfossils and Ca-S-O (gypsum) and K-Fe-S-O (jarosite) around them was demonstrated. Fig. 3(b) shows morphologically different small fossilized cells of unknown micro-organisms.

The SEM-BSE image (Fig. 3c) is an example of what could be called 'mineral replacement', where the complete substitution of organic structures by minerals rich in $\mathrm{Si}-\mathrm{Al}-\mathrm{Na}-\mathrm{O}$ took place. In this example, the interior structure of fossilized 

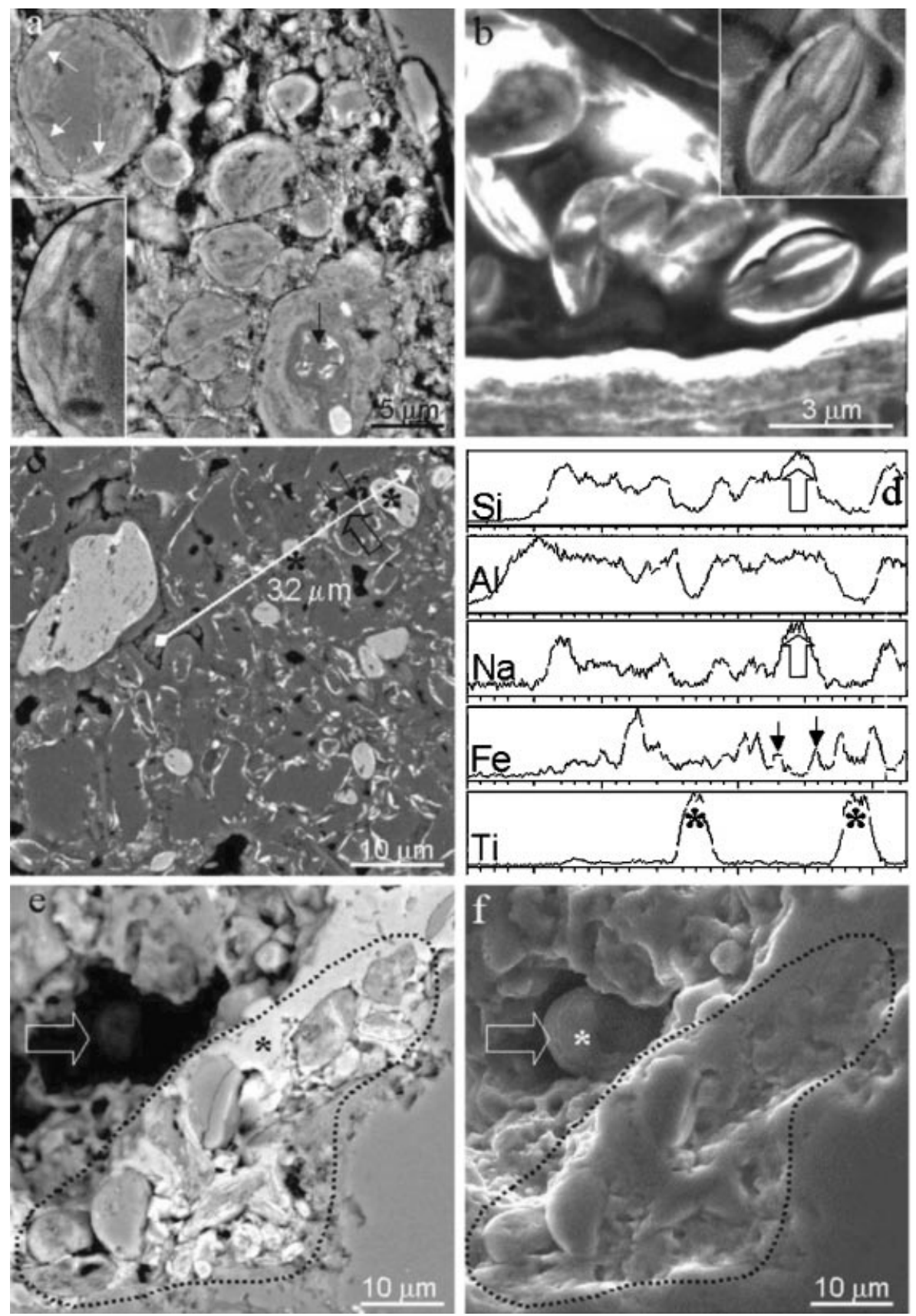

Fig. 3. Microfossils detected in Mt Fleming sandstone. (a) SEM-BSE images of permineralized cryptoendolithic micro-organisms; white arrows, chloroplast with thylakoid structures; black arrow, pyrenoid zone; inset, detail of chloroplasts indicated by white arrows. EDS point analysis revealed a variable Si-Al-Na-K-Fe-S-Ti-O content within the microfossils and the presence of Ca-S-O (gypsum) and K-Fe-S-O (jarosite) around the fossilized cells. (b) SEM-BSE image of fossilized cells of unidentified micro-organisms showing the presence of Si-Al-FeO. (c) SEM-BSE image of cells fossilized by a mineral replacement process; black arrows indicate relics of Fe-rich cell walls; asterisks indicate TiO-rich fossilized cells; white line indicates the position of the EDS microprobe scan-line profile. (d) EDS scan-line profiles showing relative concentration changes in $\mathrm{Si}, \mathrm{Al}, \mathrm{Na}, \mathrm{Fe}$ and Ti along the white arrow in (c); open arrow indicates increased $\mathrm{Si}$ and $\mathrm{Na}$ in the interior of the fossilized cell marked in (c); black arrows indicate increased Fe in fossilized cell walls; asterisks indicate TiO-rich cell fossils with bright BSE contrast in (c). (e) SEM-BSE and (f) SEM-SE images of the same area of the sample; dotted line indicates an area with fossilized cells embedded in jarosite (black asterisk in (e)); open arrow indicates the presence of a live or mummified cell; white asterisk indicates the presence of $\mathrm{C}$ and $\mathrm{O}$ in a non-mineralized cell demonstrated by EDS point microanalysis.

cells (probably algae) cannot be observed. However, cell walls containing the highest Fe concentration may be clearly identified (black arrows in Fig. 3c and black arrows in the EDS microprobe profile - Fig. 3d). The inner fossilized cells show higher $\mathrm{Si}$ and $\mathrm{Na}$ levels (empty arrow in Figs $3 \mathrm{c}$ and d) than the outer fossil spaces. However, during fossilization, some of the cells (bright fossils in the BSE signal in Fig. 3c) mainly absorbed Ti, as shown by the microprobe profile in Fig. 3(d) 


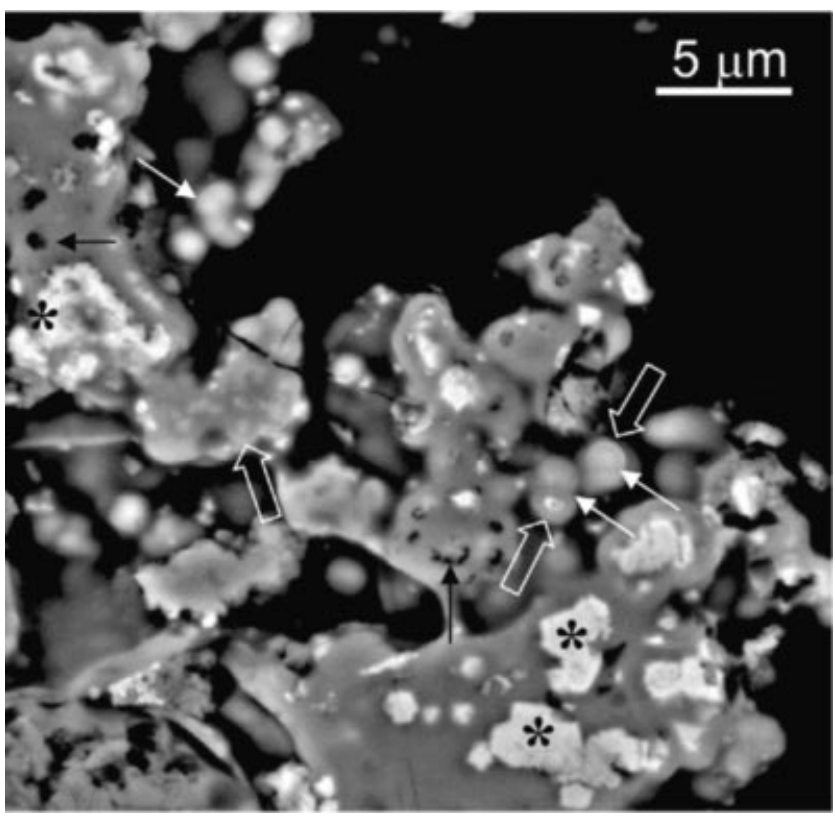

Fig. 4. SEM-BSE image of cooccoid bacterial microfossils found in Mount Fleming sandstone; white arrows, cells in the process of division; open white arrows, cell wall remains; black arrows, remnants of organic matter and asterisks, jarosite (K-Fe-S-O determined by EDS microanalysis).

(asterisks). This difference in elements suggests multiple episodes of mineralization with intervening organic degradation, rather than the primary replacement of organic materials at the time of infiltration.

The next figures (Fig. 3e and f) present SEM-BSE and SEM-SE images of the same area of fossilized cells embedded in a jarosite matrix (area defined by dotted line). Note that in the SEM-SE topographic image (Fig. 3f), it is not possible to visualize the microfossils. Yet in this micrograph, a live or mummified cell $(\sim 12 \mu \mathrm{m}$ in diameter) may be seen in close proximity to the microfossils (open arrow in Fig. 3f). EDS point analysis, mainly indicating the presence of organic matter, and the lack of a substantial BSE signal (open arrow in Fig. 3e) clearly confirms the presence of a live (mummified) cryptoendolithic cell within the Mt Fleming rock. The appearance of live cells (several observed in other parts of this rock) could be attributed to the relatively recent colonization of this rock containing microfossils.

Given the early worsening of environmental conditions on Mars, it is probable that life on this planet was limited to small prokaryotic forms such as bacteria. Fig. 4 presents an SEMBSE image of a cluster of spherical ( $\sim 1.6 \mu \mathrm{m}$ in diameter) inorganic (composed of $\mathrm{Si}$ and $\mathrm{O}$ ) bacteriomorphs, many of which are joined together. Some of these biomorphs show an internal structure (they were cut for SEM-BSE observation), in which only the cell walls may be discerned (open white arrows in Fig. 4). Many coccoidal microfossils are embedded within the silica matrix, and, in places, remnants of organic matter (dark spots in the SEM-BSE image) can be observed inside fossilized cells (black arrows in Fig. 4). Jarosite (asterisks in Fig. 4) inclusions in the silica matrix were identified by EDS microanalysis. These spheres exhibit the characteristics of bacterial fossils: they are similar in size range; their shape is typical of that of coccoid bacteria; they occur in large groups (similar to bacterial colonies); they are associated with remnants of organic matter and biofilm-like structure; in some cases cell-wall structure have been observed; and last and foremost, they show a distinct cell division process (white arrows in Fig. 4). It is possible for amorphous silica precipitating as spheres to show features similar to cell division, but in our study the spheres always appear to be of uniform size and fossil cells in mid division show cell wall remains (open arrows in Fig. 4).

The authenticity of the features described elsewhere as cryptoendolith microfossils was established by their fulfilment of the criteria for 'biogenicity' described by McKinley et al. (2000). The structures observed here were common and morphologically similar in size and shape to live microorganisms present in Ross Desert rocks. Moreover, in many cases, well-preserved cell walls, organic matter remains, cell division and ultrastructural remnants of cytoplasm components could be discerned in the SEM-BSE images. These findings also point to the dissimilarity between these and abiologic structures. Given the presence of live or mummified endoliths within the rock, we consider that further criteria for microfossils such as association with biofilms and geologic and evolutionary contexts were also met.

\section{Conclusions}

The presence of cryptoendolithic micro-organism fossils within the rocks of the hostile cold, dry environment of the $\mathrm{Mt}$ Fleming Ross Desert was demonstrated by the application of the non-invasive, non-destructive in situ SEM-BSE technique accompanied by EDS microanalysis. This cell-scale resolution technique seems to be highly sensitive for the in situ evaluation of the degree of metamorphic alteration of preserved microfossils, not only allowing a morphological description but also chemical analysis on the microscale, which, according to Conrad \& Nealson (2001), is an essential tactic for exploring fossil evidence.

Findings indicate that the in situ examination of the Antarctic rock interior using SEM-BSE (EDS) research strategies possibly represents the best option available for the identification and characterization of these traces of past life in their substrate.

Given that the Antarctic Ross Desert and, in particular, the extreme cold and dry zone of Mt Fleming is considered to be a terrestrial analogue of the early Mars environment, similar cryptoendolith fossils might be expected to occur in Martian rocks. It is scheduled that a decade from now, rock and regolith samples will be collected from Mars for research purposes. Only adequately chosen investigation strategies, appropriate in situ techniques, and particularly experience gained in searching for traces of past biological activity will serve to provide more insight into the possibility of past life on Mars. 


\section{Acknowledgements}

Thanks are due to Professor E.I. Friedmann for supplying the Antarctic rock samples and for constructive discussion, to A. Burton for the English revision, to R. Rodriguez Ochoa for comments, and to F. Pinto and X. Alcobé for technical assistance. This study was funded by grant number ANT990680-C02-02 of the Plan Nacional I+D and BOS2000-1121.

\section{References}

Ascaso, C. (2000). Lichens on rock substrates: observation of the biomineralization processes. In New Aspects in Cryptogamic Research, contribution in honour of Ludger Kappen, eds Schroeter, B., Schlensog, M. \& Green T.G.A., pp. 127-135. Gebrüder Borntraeger, Berlin.

Ascaso, C. \& Wierzchos, J. (1994). Structural aspects of the lichen-rock interface using back-scattered electron imaging. Bot. Acta 107, 251-256.

Ascaso, C., Wierzchos, J. \& de los Rios, A. (1995). Cytological Investigations of lithobiontic micro-organisms in granitic rocks. Bot. Acta 108, 474-481.

Ascaso, C., Wierzchos, J. \& de los Rios, A. (1998). In situ investigations of lichens invading rock at cellular and enzymatic level. Symbiosis 24, 221-234.

Awramik, S.M., Schopf, J.W. \& Walter, M.R. (1983). Filamentous fossil bacteria from the Archean of Western Australia. Precambrian Res. 20, 357-374.

Barker, W.W., Welch, S.A. \& Bannfield, J.F. (1997). Biochemical weathering of silicate minerals. In Geomicrobiology: Interactions between Microbes and Minerals, eds Bannfield, J.F. \& Nealson, K.H., pp. 391-428. Mineralogical Society of America, Washington, DC.

Boyce, C.K., Hazen, R.M. \& Knoll, A.H. (2001). Nondestructive, in situ, cellular-scale mapping of elemental abundances including organic carbon in permineralized fossils. Proc. Natl. Acad. Sci. 98, 5970-5974.

Conrad, P.G. \& Nealson, K.H. (2001). A non-Earthcentric approach to life detection. Astrobiology 1, 15-24.

Davis, W.L. and McKay, C.P. (1996). Origins of life: a comparison of theories and applications to Mars. Origins Life Evol. Biosphere 26, 61-73.

Ferris, F.G., Fyfe, W.S. \& Beveridge, T.J. (1988). Metalic ion activity by Bacillus subtilis: implications for the fossilization of micro-organisms. Geology 16, 149-152.

Fortin, D., Ferris, F.G. \& Beveridge, T.J. (1997). Surface-mediated mineral development by bacteria. Rev. Mineralogy 35, 161-180.

Francis, S., Margulis, L. \& Barghoorn, E.S. (1978). On the experimental silicification of micro-organisms in the fossil record. Precambrian Res. 6 , 65-100.

Friedmann, E.I. (1980). Endolithic microbial life in hot and cold deserts. Origins Life Evol. Biosphere 10, 223-235.

Friedmann, E.I. (1982). Endolithic micro-organisms in the Antarctic cold desert. Science 215, 1045-1053.

Friedmann, E.I. \& Ocampo, R. (1976). Endolithic blue-green algae in the Dry Valleys: primary producers in the Antarctic desert ecosystem. Science 193, 1247-1249.

Friedmann, E.I. \& Weed, R. (1987). Microbial trace-fossil formation, biogenous and abiotic weathering in the Antarctic cold desert. Science 236, 645-752.

Friedmann, E.I. \& Koriem, A.M. (1989). Life on Mars: how it disappeared (if it was ever there). Adv. Space Res. 9, 167-172.

Friedmann, E.I., Friedmann, R.O. \& McKay, C.P. (1981). Adaptations of cryptoendolithic lichens in the Antarctic desert. In Colloque sur les Écosystèmes Subantarctiques, Paimpont, no. 51, pp. 65-70. CNFRA, Paris.

Friedmann, E.I., McKay, C.P. \& Nienow, J.A. (1987). The cryptoendolithic microbial environment in the Ross Desert of
Antarctica: satellite-transmitted continuous nanoclimate data, 1984 to 1986. Polar Biol. 7, 273-287.

Friedmann E.I., Hua, M. \& Ocampo-Friedmann, R. (1988).

Cryptoendolithic lichen and cyanobacterial communities of the Ross Desert Antarctica. Polarforschung 58, 251-259.

Friedmann, E.I., Druk, A.Y. \& McKay, C.P. (1994). Limits of life and microbial extinction in the Antarctic desert. Antarctic J. US 29, 176-179.

Friedmann, E.I., Wierzchos, J., Ascaso, C. \& Winklhofer, M. (2001). Chains of magnetite crystals in the meteorite ALH84001: evidence of biological origin. Proc. Natl. Acad. Sci. 98, 2176-2181.

Garcia-Ruiz, J.M. (1999). Morphological behaviour of inorganic precipitation system. Instruments, Methods and Missions for Astrobiology vol. II, p. 3755. SPIE.

Golubic, S.I., Friedmann, E.I. \& Schneider, J. (1981). The lithobiontic ecological niche, with spatial reference to micro-organisms. J. Sediment. Petrol. 51, 475-478.

Hofman, H. \& Schopf, J.W. (1983). Early Proterozoic micro-fossils. In Earth's Earliest Biosphere, ed. Schopf, J.W., pp. 321-360. Princeton University Press, Princeton, NJ.

House, C.H., Schopf, J.W., McKeegan, K.D., Harrison, T.M. \& Stetter, K.O. (2000). Carbon isotopic composition of individual Precambrian microfossils. Geology 28, 707-710.

Joy, D.C. (1991). An introduction to Monte Carlo simulation. Scanning Microsc. 5, 329-337.

Kappen, L. (1993). Lichens in the Antarctic region. In Antarctic Microbiology, ed. Friedmann, E.I., pp. 433-490. Wiley-Liss, New York.

Kennedy, A.D. (1993). Water as limiting factor in the Antarctic terrestrial environment: a biogeographical synthesis. Arctic Alpine Res. 25, 308-315.

Konhauser, K.O., Phoenix, V.R., Bottrell, S.H., Adams, D.G. \& Head, I.M. (2001). Microbial-silica interactions in Icelandic hot spring sinter: possible analogues for some Precambrian siliceous stromatolites. Sediment., 48, 415-433.

Leo, R.F. \& Barghoorn, E.S. (1976). Silicification of wood. Bot. Mus. Leafl. Harv. Univ. 25, 1-47.

Liebig, K.F., Westall, F. \& Schmitz, M. (1996). A study of fossil microstructures from the Eocene messel formation using transmission electron microscopy. Neues Jahrb. Geol. Paläntol. Monatsh 4, 218-231.

McKay, C.P. (1993). Relevance of Antarctic microbial ecosystems to exobiology. In Antarctic Microbiology, ed. Friedmann, E.I., pp. 593-601. Wiley-Liss, New York.

McKay, C.P., Friedmann, E.I., Wharton, R.A. \& Davies, W.L. (1992). History of water on Mars: a biological perspective. Adv. Space Res. 12, 231-238.

McKinley, J.P., Stevens, T.O. \& Westall, F. (2000). Microfossils and paleoenvironments in deep subsurface basalt samples. Geomicrobiol. J. 17, 43-54.

Nordstrom, D.K. (1982). Aqueous pyrite oxidation and the consequent formation of secondary iron minerals. In Acid Sulfate Weathering. Soil Sci. Soc. Am. Spec. Publ., vol. 10, ed. Kittrick, J.A., Fanning, D.S., Hossner, L.R., Kral, D.M. \& Hawkins, S., pp. 37-56.

Russell, N.C., Edwards, H.G.M. \& Wynn-Williams, D. (1998). FT-Raman spectroscopic analysis of endolithic microbial communities from Beacon sandstone in Victoria Land, Antarctica. Antarctic Sci. 10, 63-74.

Schopf, J.W. (1975). Modes of fossil preservation. Rev. Palaeobot. Palynol., 20, 27-53.

Schopf, J.W. \& Walter, M.R. (1983). Archean microfossils: new evidence of ancient microbes. In Earth's Earliest Biosphere, its Origin and Evolution, ed. Schopf, J.W., pp. 214-239. Princeton University Press, Princeton, NJ.

Steele, A., Goddard, D., Beech, I.B., Tapper, R.C., Stapleton, D. \& Smith, J.R. (1998). Atomic force microscopy imaging of fragments from the Martian meteorite ALH84001. J. Microsc. 189, 2-7.

Sun, H.J. \& Friedmann, E.I. (1999). Growth on geological time scales in the Antarctic cryptoendolithic microbial community. Geomicrob. J. 16, 193-202.

Westall, F. (1994). Silicified bacteria and associated biofilm from the deep- 
sea sedimentary environment. In Micro-organisms, Facies Analysis and Fossil Diagenesis. Kaupia, Darmstädter Beitr Naturgeschichte, vol. 4, eds Schmitz, M. \& Ernst, K., pp. 29-43.

Westall, F. (1999). The nature of fossil bacteria: a guide to the search for extraterrestrial life. J. Geophys. Res. 104, 16 437-16 451.

Westall, F., Boni, L. \& Guerzoni, M.E. (1995). The experimental silicification of micro-organisms. Palaeontology 38, 495-528.

Wierzchos, J. \& Ascaso, C. (1994). Application of back-scattered electron imaging to the study of the lichen-rock interface. J. Microsc. 175, 54-59.
Wierzchos, J. \& Ascaso, C. (2001). Life, decay and fossilisation of endolithic micro-organisms from the Ross Desert, Antarctica: suggestions for in situ further research. Polar Biol. 24, 863-868.

Wierzchos, J., Ascaso, C., Sancho, L.G. \& Green, A. (2002). Iron-rich diagenetic minerals are biomarkers of microbial activity in Antarctic rocks. Geomicrob. J. (in press).

Wilde, S.A., Valley, J.W., Peck, W.H. \& Graham, C.M. (2001). Evidence from detrital zircons for the existence of continental crust and oceans on the Earth 4.4 Gyr ago. Nature 409, 175-178. 